\title{
Making Sense of Madness: Mental Disorders and the Practices of Case History Writing in the Early Nineteenth Century
}

\author{
Janka Kovács \\ Eötvös Loránd University \\ kovacs.janka@btk.elte.hu
}

The article focuses on interpretations of madness in early nineteenth-century Hungary medical practice from a comparative perspective. By relying on the methodological approach of the anthropology of writing and the analytical considerations offered by Michel Foucault's 1973-1974 lectures on Psychiatric Power, the article discusses the formalized and standardized practices of case history writing. It draws on sources from the teaching clinics at the universities of Pest and Edinburgh, as well as the largest mental asylums in the Habsburg Monarchy in Vienna (est. 1784) and Prague (est. 1790), and the ideal type of mental asylums at the turn of the eighteenth and nineteenth centuries, the York Retreat (est. 1796). In doing so, an attempt is made to reconstruct both the physicians' gaze and (to a certain extent) the patients' view, and by examining the therapeutical regime of each hospital and its correlations with the institutional background, uncover whether madness was perceived as a pathological somatic or psychological state in the medical practice of these institutions. This is in and of itself a fundamental question if we seek to understand changing attitudes towards the mad and their curability in a period of transition from a "world without psychiatry" to a "world of psychiatry," when specialized care was still not an option for many, especially in the East Central European region.

Keywords: history of psychiatry, case history, medical gaze, clinical practice, medical writing

On July 20, 1812, Anna Maria Navratil, a 50-year-old female patient afflicted with a serious illness, was taken to the teaching clinic of the Medical Faculty at the University of Pest. Upon admission, she was diagnosed with an enigmatic disease, bysteria, the interpretation of which requires caution. ${ }^{1}$ She was undernourished and had a weak bodily posture, and she presented the following symptoms: heavy palpitation and pulse, stiffness in the neck, slow metabolism, hard stool, plentiful but watery urine, and globus bystericus, the suffocating feeling of a lump in the throat, typical of hysteric patients. She was also melancholic, sad, and sensitive, and her face mirrored desperation. The woman's road to

1 SEL, 50/a, Historiae Morborum (referred to henceforth as HM), 246. 
recovery (or at least an asymptomatic state) was followed closely by the medical students completing their clinical practice in the wards, as was done in the cases of hundreds of patients treated at the clinic. These day-to-day observations were recorded in case histories, the length and detailedness of which varied according to the personal habits and preferences of each student. The structurally strict and tight narratives consisted of the following standard elements: the day of admission and basic personal data (age, sex, occupation, religion), the anamnesis encompassing the patients' family history and life events pertaining to illness, the diagnosis and etiology of the disease, the progress of the disease, and the day of death or discharge. In case of discharge, the patient's current condition was also recorded (perfectus or imperfectus).

Observation as the practice of collecting and interpreting data is age-old. In medicine, however, the epistemic method of writing, the aim of which is the accumulation, recording, and structuring of information, became common only in the sixteenth century, and in medical education it was introduced as a formalized practice as late as the eighteenth century. ${ }^{2}$ Compulsory case history writing was introduced at the teaching clinic at the University of Pest in $1784^{3}$ in order to counterbalance the dominance of "bookish knowledge" in dissertation writing, and it remained a prerequisite for a medical degree until the 1840s. Beginning in the 1810s, mentally ill patients, among them hysteric or melancholic individuals, were admitted to the clinic in increasing numbers, and their progress was recorded in the standardized and prescribed observational categories of case histories. This study delves into these materials and by juxtaposing them to case histories written in diverse institutional settings, It also explores patterns and tendencies in the interpretations of "mental" disorders in an era when the early forms of mental normalization were already underway.

2 On this, see for example: Becker and Clark, Little Tools of Knowledge; Blair, "Reading Strategies"; Daston, "Taking Note(s)"; Daston, "The Empire of Observation"; Goody, The Logic of Writing. On the anthropology of writing and psychiatry, see Aaslestad, The Patient as Text, Andrews, "Case Notes, Case Histories"; Andrews and Scull, Customers and Patrons of the Mad-Trade; Berkenkotter, Patient Tales; Craig, "Enquire into All the Circumstances of the Patient Narrowly"; Hess, "Formalisierte Beobachtung"; Hess and Ledebur, "Taking and Keeping"; Hess and Mendelsohn, "Case and Series"; Hunter, Doctor's Stories; Hurwitz, "Form and Representation"; Ingram, The Madhouse of Language; Kennedy, A Curious Literature; "Empiricism in the Library"; Pomata, "Sharing Cases." On the historical anthropology of medical writing in Hungary, see Krász, "Az adatoktól az információig”; Krász, "Táblázatokba zárt tudás?”; Krász, “'Observing to describe, describing to observe'."

3 Krász, "Theoria medica és praxis medica," 1035-36; Rédei, Historiae morborum. 
In the case of Hungary, the insights offered by the case histories are unique in certain respects. First, there are comparatively few hospital case histories which shed light on the day-to-day experiences of healing. Second, since Hungary had no special institution (either an asylum or a designated hospital ward) to provide at least rudimentary care for the insane until the establishment of the first wards in the Buda hospital of the Brothers of Mercy in the 1830s, the Schwartzer Private Lunatic Asylum (which opened in 1850), or the Lipótmező Royal National Asylum (which opened in 1868), municipal general hospitals, policlinics, and hospitals operated by religious orders (the Brothers of Mercy and the Sisters of Saint Elizabeth) admitted them. Therefore, however sparse the available materials are (and thus the number of mentally ill patients on which some information has survived), the diagnostic and healing practices of the Pest policlinic can be taken as representative for "mental normalization" in Hungary in the period under study.

The primarily somatic approach to mental disorders might also be a direct consequence of the way in which knowledge concerning psychology was disseminated in medical education. From the early 1800s onwards, gradually replacing the dominant approach of Hippocratic and Galenic medicine, more modern theoretical and practical approaches were introduced at the medical faculties at the universities of Vienna, Prague, and Pest. Though individual courses on psychology/psychiatry were not offered until the 1840s, when in Prague and Vienna the first proposals were sent to the Court Commission of Studies (Studienhofkommission) by the primary physicians at the Vienna and Prague asylums, increasing attention was being paid to knowledge concerning psychology. Knowledge of psychology was part of the compulsory training in philosophy (itself a prerequisite of medical education) at the two-year and three-year programs offered by colleges and the philosophy faculties of the universities, either incorporated into courses on logic or taught individually as empirical psychology. Furthermore, from the turn of the eighteenth and nineteenth centuries, basic psychological knowledge was filtered into core medical courses on physiology, pathology, therapy, medical police, and forensic medicine, with the body-soul problem and the problem of mental disorders often being explained from neurological and "social" points of view. ${ }^{4}$ The latter, gaining ground in the subsequent decades, viewed mental disorders either as

4 On psychological knowledge in medical education in the Habsburg Monarchy at the turn of the eighteenth and nineteenth centuries, see Kovács, "Az orvostudomány 'legsetétebb mezeje.." 
diseases of civilization (for example, the consequences of an urban or scholarly lifestyle) and considered the mentally ill in their broader social contexts as individuals to be defended from and also a "danger" to society at large. This, however, as the case histories reveal, rarely surfaced in the context of hospital practice. It remained within the domain of theoretical discourses in textbooks or dissertations.

In attempting to grasp the interpretations of mental disorders recorded in case histories, I focus on the case histories' layout, seriality, formalized structure, and the cognitive practices written into the narratives and their links with knowledge production and the interpretation of different phenomena in medical practice. The means of interpretation, however, cannot be understood without paying close attention to the correlations between the methodology of writing and the institutional background, which could shed light on whether the "mental" disorders appearing in the case histories under discussion were indeed understood, approached, and handled as mental disorders with a psychological elucidation in mind or whether they were seen and treated as first and foremost somatic diseases disguised as mental maladies. To make sense of the practices at the teaching clinic in Pest, comparative materials, among them the records of hospital administration, statistics, case histories, and patient records will be explored from different types of institutions, ranging from the teaching clinic at the Royal Infirmary of Edinburgh, which operated in a similar configuration as the Pest clinic, to the early asylums of the Habsburg Monarchy in Vienna and Prague and the model of mental asylums in the period, the York Retreat, which was founded in 1796.

In addition to drawing on the methodological approach of the anthropology of (medical) writing, the study's inquiries are also informed and inspired by Michel Foucault's lectures on psychiatric power held at the Collège de France between 1973 and $1974^{5}$ and Roy Porter's seminal 1985 article advocating the inclusion of a patient's view in medical history writing, ${ }^{6}$ which has been introduced and applied in research with more or less success for the past few decades. ${ }^{7}$ Taking their argumentation as a starting point, I will focus on the following aspects: 1. the ritual of questioning and confession, and the incorporation of the physician's gaze and the patient's perspective into the narratives, 2 . the

5 Foucault, "23 January 1974"; Foucault, “30 January 1974."

6 Porter, "The Patient's View."

7 See Bacopoulos-Viau and Fauvel, "The Patient's Turn"; Condrau, "The Patient's View Meets the Clinical Gaze"; Reaume, "From the Perspectives of Mad People." 
importance of pathological anatomy and "family history" in making diagnoses, 3. the applied therapeutical regimes and the length of stays in hospitals, which could be revealing with regards to the preferences of either a psychological or a somatic approach in "mental" normalization.

\section{Managing Mental Disorders: Approaches from Teaching Clinics to Lunatic Asylums}

As the layout and structure of the case histories and patient records on the basis of which conclusions can be ventured concerning the physicians' gaze, the patients' progress, and the interpretations of diseases depended heavily on the given institutions' administrative practices, the following section will provide a summary of the most significant institutional tendencies and the nature of the surviving sources.

The richest collection of case histories survives from the teaching clinic at the University of Pest, where the purpose of recording the patients' cases was twofold. First, case histories were written in partial fulfilment of medical degrees from 1784, following the Viennese example. For his final exam, each student had to summarize the progress of two or three patients chosen from a larger pool with a wide array of diseases. ${ }^{8}$ The structure of these narratives is in most cases clear and logical, and the main points are well articulated. Second, case history writing was also a compulsory part of clinical practice for fourth-year and fifth-year medical students, as testified by a diverse group of materials on hospital administration (patient records, statistics, case histories, meteorological observations) in Ferenc Bene's (1775-1858) collection, which was preserved in the Manuscripts Archive of the National Széchényi Library in Budapest.

The teaching clinic was led by Ferenc Bene, chief physician of Pest, dean of the medical faculty (1807-1809) and rector of the University of Pest (1810), and a propagator of smallpox vaccination in Hungary between the 1810s and the middle of the 1840s. In this period, students were required to write case histories on a monthly basis, and these histories were then handed in to him for evaluation (in many cases, the documents were signed by him). In comparison with the exam materials, these narratives are less detailed and less well-structured, but in all cases they mirror the given medical student's individual style, preparedness, and diligence, and they also show the everyday "raw" experiences involved in

8 SEL 50/a, Historiae Morborum. See the two case histories on hysteria: SEL HM 246, HM 313. 
working in close proximity to diseases, the students' progress, and the physicians' approaches to the students. ${ }^{9}$ In addition to the longer case histories, on which the second part of this study draws, shorter summaries and reports (synoptica relatio), sometimes reflecting on the same cases as the longer narratives and clinical journals encompassing hospital statistics, were also prepared, in most cases by the assistant physicians at the clinic. Depending on the habits, erudition, and individual preferences of the physicians, the clinical journals had different layouts, and they often varied in the extent to which they went into detail, but their structure remained the same, including statistics (the number of all admitted patients in the previous six months or year, as well as the number of discharged and remaining patients and deaths) and a narrative part summarizing "interesting" or "curious" cases arranged into seven categories. ${ }^{10}$

As highlighted earlier, the two types of case histories, the practice and exam materials, were similar in their structure but could mirror different everyday experiences of hospital life and the progress of individual cases, as well as the physicians' individual approaches to health, illness, and therapy. However, both types offer a glimpse into how, sometimes breaking with the "bookish" tradition of medical education, medical students, observing their patients' progress, documented and at the same time interpreted and approached "madness" and the most frequently described and diagnosed mental maladies in the period and the connections these interpretations had with the content of their curriculum.

From among the case histories written at the teaching clinic at Pest between 1787 and 1847, I have chosen to focus on a narrower period between 1812 and 1828. Prior to 1812 , no case histories were written on mental patients, while after 1828 the approach to mental disorders altered in medical education, with changes in both quantitative and qualitative factors, as shown, for example, by the number of admissions, changes in the curriculum, and the thematic spectrum of dissertations. I chose cases for further exploration in which the diagnoses were fully or partially related to mental disorders, mostly the four

9 The longer case histories written during clinical practice were later organized into 44 volumes. Today, they are held in OSZK Kt., Quart. Lat. 2164. Vols. 1-44.

10 The categories (for example, fevers, inflammations, rashes and skin diseases, the disorders of the excretory system) are based on Johann Peter Frank's classification used in De curandis hominum morbis (17921820). This is referred to in OSZK Kt., Quart. Lat. 2168. Vol. I, 2v. See the clinical journals and patient statistics in OSZK Kt., Quart. Lat. 2166; Quart. Lat. 2169; Quart. Lat. 2172; SEL, 1/g, Annual Reports of the Clinics of the Medical Faculty, 1825-1835, Boxes 1-3. 
most common "traveling concepts,"11 hysteria, hypochondria, melancholy, and mania, which were familiar since Antiquity but which have been reimagined and interpreted over the course of the centuries in light of newer theories, such as dualism, mechanical theories, animism, vitalism, and the findings of neurology. As revealed by the Hungarian clinical cases, these maladies were still commonly diagnosed in the early nineteenth century, even though this period saw a slow and gradual transition towards a more nuanced classification of mental disorders (at least in Western Europe and, as we will see in the discussion of diagnostic practices at the Vienna and Prague asylums, to some extent in the East Central European region too) with the work of German physician Johann Christian August Heinroth (1773-1843), the French Philippe Pinel (1745-1826), and his pupil, Jean-Étienne Dominique Esquirol (1772-1840). According to their classifications, some of the categories partly became devoid of their original meaning or were reconsidered and "fell apart."

In some of the cases I have selected, mental disorders were concomitant with other diseases and developed in relation to or as a consequence of either neurological (debilitating headaches, epilepsy, St. Vitus's dance, also known as Sydenham's chorea) or gastrointestinal diseases. However, the neurological disorders that were not identified as mental maladies and were not accompanied by mental symptoms were not considered. After taking these factors into consideration, I chose 22 longer case histories which include the standard categories of observation (anamnesis, diagnosis, etiology, prognosis, the progress of the disease, therapy). ${ }^{13}$

As the policlinic of the University of Pest mostly admitted surgical cases, pregnant women, patients with fevers, skin diseases, or inflammations that could make good teaching cases, the low number of mental patients in the statistics, clinical journals, and case histories should not come as a surprise. Furthermore,

11 In approaching disease concepts, especially those classified as "mental," I find it useful to apply the term introduced by Dutch cultural theorist Mieke Bal. Bal characterizes concepts as intellectual tools which, by traveling from one context or discipline to another, could gain new meanings in their different cultural, linguistic, and social settings. At the same time, they can retain some of their older interpretations in the process. The representations of the age-old concepts of mania, melancholy, hysteria, and hypochondria, which were still the four most commonly diagnosed mental disorders at the turn of the eighteenth and nineteenth centuries, can be interpreted in this framework. Cf. Bal, Travelling Concepts, 22-55.

12 Chase, The Making of Modern Psychiatry, 29-30.

13 From among the 22 cases, the progress of four patients was recorded in both the longer case histories and the brief, synoptic summaries. Cf. OSZK Kt., Quart. Lat. 2168. Vol. I, 36r-38r. (Elisabetha Szabó); Quart. Lat. 2168. Vol. III, 44r-v. (Anna Obst); Quart. Lat. 2168. Vol. XI, 30r-v. (Anna Skarlein); Quart. Lat. 2172. Vol. II, 7r-v. (Barbara Roletsky). 
if we consider the dominance of one particular disease, hysteria (and to a lesser extent its "male counterpart," hypochondria), the number of mental diseases approached from and diagnosed based on a psychological framework are even fewer in number. As opposed to mania or melancholy, which were primarily diagnosed based on mental and behavioral symptoms, at the time hysteria and hypochondria could easily be interpreted as somatic diseases that could yield physical therapeutics if we consider their symptomatology, even though they were more often than not accompanied by mental symptoms. The dominance of the somatic approach, thus, is pinpointed by the low proportion of mental maladies and high incidence of maladies disguised as such. From among the 22 patients, 18 were diagnosed with hysteria, one with hypochondria, one with erotomania (a disorder characterized by an individual's delusions of another person being infatuated with them), one with melancholy, and one with delirium tremens. ${ }^{14}$ Hence, the case histories of the teaching clinic of Pest shed light on interpretations of hysteria and the practice of diagnosing and healing along the lines of somatic medicine, lacking a psychological approach which was, to some extent, already in use in the diagnostic and therapeutic practices in the first asylums of the Habsburg Monarchy or in model institutions, such as the aforementioned York Retreat.

Among the universities operating a teaching clinic in Europe at turn of the eighteenth and nineteenth centuries, ${ }^{15}$ the teaching wards at the Royal Infirmary of Edinburgh showed remarkable similarities with the policlinic in Pest. Very much like the reform measures launched by Gerard van Swieten (1700-1772) in the mid-eighteenth century in Vienna, which also had a profound impact on medical education in Hungary, the reform of the Medical Faculty of the University of Edinburgh established in 1726 was also implemented by three pupils of Herman Boerhaave (1668-1738), Alexander Monro primus (1697-1787), John Rutherford (1695-1779), and William Cullen (1710-1790). Following the Leyden model, both in Vienna (and later in Pest) and Edinburgh emphasis was

14 OSZK Kt., Quart. Lat. 2165. Vol. I, 336v-359v (Elisabetha Szabó); Vol. III, 326r-330v (Anna Obst); Vol. V, 134r-136r (Klara Verl); Vol. V, 229r-231v (Cunigunda Gramlin); Vol. V, 235r-240v (Julia Tergoth); Vol. VI, 69r-70v (Elisabeth Enzmann); Vol. VIII, 165r-169v (Barbara Roletsky); Vol. VIII, 295r-296v (Rosalia Hany); Vol. XII, 170r-171v (Maximilianus Hirschl); Vol. XIII, 176r-178v (Anna Skarlein); Vol. XV, 139v-140v (Susanna Schedner); Vol. XVII, 136r-136v (Catharina Koháné [Mrs. Catharina Koha]); Vol. XVII, 219r-220v (Maria Steiner); Vol. XIX, 252r-253v (Franciscus Schober); Vol. XXI, 119r-124r (Anna Streditzin); Vol. XXIII, 43v-45v (Fekete Sigismundus); Vol. XV, 196v-198v (Julianna Koszonits); Vol. XVI, 161v-163r (Anna Beck); Vol. XVIII, 122r-125v (Johannes Slavik).

15 On Berlin and Paris, see Hess, "Formalisierte Beobachtung." 
put on bedside teaching and empirical observation, creating the most modern spaces of medical education in Europe.${ }^{16}$ By this time, Edinburgh diverged from the English model still followed in Cambridge and Oxford, which relied on an outdated system of theoretical lectures and observation, eliminating clinical teaching almost completely. ${ }^{17}$ As for the practices of admission, capacity, and patient numbers, there are further similarities between the teaching wards of the Royal Infirmary and the teaching clinic of Pest: in Edinburgh, 20 to 50 patients were admitted on a monthly basis, whereas in Pest the figures were between 20 and $40 .{ }^{18}$ The clinical case histories written in Edinburgh between the 1790s and the $1810 \mathrm{~s}^{19}$ reveal rather similar tendencies to what we have observed in the case of the Pest policlinic. Though medical students in Edinburgh played a somewhat more passive role in the actual treatment of patients, empirical observation, the recording of day-to-day experiences, and the practice of case history writing were at the heart of medical education from the mid-eighteenth century onwards.

The collections of case histories, however, were preserved in a different format: while in the case of Pest, student reports were edited into volumes posteriorly, in Edinburgh, each medical student kept his own books, in which they recorded (or in some cases, copied) their case histories in a different structure from what we have seen in the case of Pest. Though the standard categories of observation also prevail and govern the physicians' gaze here, medical students in Edinburgh followed different editorial practices. They recorded their daily observations chronologically in the form of diary-like entries in volumes, which allowed them to follow the treatment of different patients simultaneously. Therefore, the case histories follow a rather fragmented structure, with cross-references and indices. This less clear-cut structure, however, allows the researcher to catch a glimpse into the cognitive practices written into the broken narratives. As for the representation of mental disorders in the casebooks, though the Royal Infirmary admitted mental patients in lesser

16 See Risse, "Clinical Instruction in Hospitals."

17 Craig, "Enquire into All the Circumstances"; Geyer-Kordesch, "Comparative Difficulties"; Risse, Hospital Life.

18 Risse, Hospital Life, 272; SEL, 1/g, Boxes 1-3.

19 Risse, Hospital Life, 272-73; Craig, "Enquire into All the Circumstances." See the case histories RCPE DEP/ABJ/1-2: Men's Cases (1800-1801); DEP/1/1/5-9: Women's Cases (1801); DEP/AWP/2/16: Cases taken from the Clinical Journals of the Royal Infirmary of Edinburgh (1809-1811); DEP/ AWP/2/7-8: Clinical case notes (1811); DEP/HOT/1: Clinical Casebook (1796-1797); DEP/LID/1: Clinical Case notes (1812). 
numbers, I have found similar ratios as in the case of Pest. The notebooks of John Abercrombie (1780-1844), who later practiced medicine in Edinburgh, William Pulteney Alison (1790-1859) and Thomas Charles Hope (1766-1844), the two Presidents of the Royal College of Physicians in Edinburgh in the following decades, and David Lithgow (?-?), a practitioner in Dublin, reveal that even though neurological diseases, especially epilepsy, counted as fashionable diagnoses in Edinburgh at the turn of the eighteenth and nineteenth centuries, ${ }^{20}$ mentally ill patients were either not admitted or were not properly diagnosed in the teaching wards. Altogether, seven patients were admitted with hysteria, two with hypochondria, and one with mania.

As a counterpoint to the policlinics and their primarily somatic approach, the early mental asylums of the Habsburg Monarchy in the late eighteenth century began to use a partially psychological approach in diagnostics and healing by the first decades of the nineteenth century. As we will see, the asylums of the Monarchy occupied a middle ground between the policlinics and model asylums, such as the York Retreat, which played a pioneering role in introducing moral therapy. Furthermore, since the hospital network and the early asylums of the Habsburg Monarchy provided the most important model for the organization of Hungarian hospitals and also the first (private) psychiatric institutions later in the nineteenth century, their practices must be taken into consideration as an immediate context of the trends in Hungary. ${ }^{21}$ Though it would be ideal to compare the general wards of the Vienna General Hospital (Allgemeines Krankenhaus) to the teaching clinic of Pest, the number of available case histories written by medical students is rather low, and the number of mental patients among them is even lower. Short case histories and the summaries of therapeutic measures in the general hospital were published based on the courses of Anton de Haen (1704-1776) and Maximilian Stoll (1742-1787). These narratives, however, rarely deal with either mental or neurological diseases, and even if they do, the "case histories" often do not follow the standard categories of observation that would enable us to fully grasp the ways in which the maladies were interpreted. ${ }^{22}$

20 See for example the following cases RCPE DEP/ABJ/1 78-81. (Andrew Smill); DEP/ABJ/1/1/2 29-31. and DEP/ABJ/1/1/3 18-25. (Robert Brown); DEP/ABJ/1/1/3 56-60. (Adam Armstrong)

21 On the hospital network, see Krász, "From Home Treatment to Hospitalisation"; Scheutz and Weiss, "Spitäler im bayerischen und österreichischen Raum"; on the institutional treatment of the insane, see Watzka, Vom Hospital zum Krankenhaus; Watzka, Arme, Kranke, Verrückte.

22 See for example Stoll, Heilungsmethode 2/1, 103-4 (Phrenesis); 111-14 (Raserey); 162-65 (Hysteria); Stoll, Heilungsmethode 3/1, 230-32 (Hypochondria); Stoll, Heilungsmethode 5/1, 23 (Hypochondria); 131-33; 1775-78. 
As for the two most significant mental asylums in the Monarchy, only printed case histories remained, which require a somewhat different approach than the manuscripts from the teaching clinics in Pest and Edinburgh. The first decades of the operation of the first purpose-built asylum on the continent, which was established by Joseph II (1780-1790) as part of the Viennese General Hospital in 1784, and the asylum, the establishment of which was initiated by Joseph II and opened under the reign of Leopold II (1790-1792) in 1790 in Prague, were summarized in two accounts published by Joseph Gottfried von Riedel, the secondary physician of the Prague asylum, in 1830 and by Michael von Viszánik, the Hungarian-born primary physician of the Viennese asylum, in $1845 .^{23}$ The printed accounts reflecting on the spatial organization, operation, healing activities, and patient statistics of the asylums contain twelve and 13 long case histories each, following the diagnostic categories included in the seventeenth-century, eighteenth-century, and early nineteenth-century nosologies of Thomas Willis (1621-1675), the English physician who played a pioneering role in neurology, François Boissier de Sauvages (1706-1767), the professor of physiology and anatomy at the University of Montpellier, and Johann Christian August Heinroth, the first professor of psychiatry. ${ }^{24}$ By applying a diverse array of categories and subcategories to describe mental disorders, the narratives of Riedel and Viszánik reveal how early psychiatric diagnostics worked in practice and how the treatments of these ailments were approached. Though Viszánik's account was published well into the nineteenth century, later than the other materials examined in this study, the structure and logic of his book mirror Riedel's account, which must have been a source on which he drew. Furthermore, he had been a long-serving physician at the institution by then, with a keen eye to its development from the early years. Also, since the Narrenturm, tcontinental Europe's first purpose-built psychiatric hospital, found in Vienna, played a central role in the developing network of asylums in the Monarchy and served as a model institution, its diagnostic and therapeutic practice are indicative of the regional approaches to "madness."

(Hysterie) Further case histories were written by medical students in the wards of the Josephinian Military Academy of Surgery, see for example the following cases: UAW Sonstige Archive, Josephsakademie (k. k. medizinisch-chirurgische Militärakademie) und Garnisonsspital, Wissenschaftliche Elaborate, Krankengeschichten, JOSEF I, no. 60; no. 61; JOSEF 3, no. 13; no. 37.

23 Riedel, Prag's Irrenanstalt; Viszánik, Leistungen und Statistik.

24 Heinroth, Lehrbuch der Störungen des Seelenlebens; Sauvages, Nosologia methodica; Willis, Pathologiae cerebri et nervosi generis specimen, 1667. 
A more specialized approach to mental normalization is revealed by the short case histories included in the patient register of the York Retreat kept from 1796. The Retreat was founded by the Quaker Tuke family, and it remained in their operation in the subsequent decades: the founder, William Tuke (17321822), was followed by his son, Henry Tuke (1755-1814), his grandson, Samuel Tuke (1784-1857), and his great-grandsons, James (1819-1822) and Daniel Tuke (1827-1895). According to the somewhat idealized accounts published by Samuel Tuke in 1813 and 1815, the institution and its practices exerted significant influence, and the Retreat served as a model institution for other asylums both in England and on the continent, especially on account of the theory and practices of moral therapy. ${ }^{25}$ As pinpointed by treatises on medical police and hospital administration, the English model and, especially, the York model had also had an impact in the Habsburg Monarchy. ${ }^{26}$ The Retreat, which devoted significant attention to religion, philanthropy, a humane approach to mental disorders, the incentive of meaningful occupation, natural environment, and conversations, ${ }^{27}$ played a vital role in introducing a psychological approach to the treatment of the insane. As for the admission, administration, diagnosing, and recording of the patients' progress, the York Retreat with its integrated practices serves as a unique example. The rather laconic, usually one-page entries in the casebooks ${ }^{28}$ of the Retreat briefly summarize the dates of the patients' admission, readmission, discharge, or death, and also their sex, occupation, the anamnesis, and the progress of their disease. As a sample, I have chosen 100 cases altogether from between 1796 and 1800 and 1815 and $1820^{29}$ which reveal the almost complete lack of a somatic approach and the dominance of the psychological (moral) approach to diagnostics and therapy.

25 The most thorough summary of the York Retreat's operation and principles is found in Digby, Madness, Morality, and Medicine.

26 See Kovács, "Elmebetegügy."

27 See the idealistic reflections on the operation of the asylum and the theory and practice of moral therapy in Tuke, Description of the Retreat; Tuke, Practical Hints.

28 See the casebooks of the York Retreat in: Borthwick Institute for Archives, University of York, York Retreat Casebooks, 1-3. RET 6/5/1/1/A (Volume 1, 1796-1828); RET 6/5/1/1/B (Volume 2, 18031820); RET 6/5/1/2 (Volume, 1828-1838). In the article, I focus on 100 cases chosen from the first volume.

29 Borthwick Institute for Archives RET 6/5/1/1/A, no. 1-50; no. 183-236. 


\section{From Soma to Psyche: Interpreting Mental Disorders}

If we seek to identify the differences between the somatic and psychological approaches to the diagnostics and the treatment of "mental" maladies recorded in the case histories, with some modifications, Michel Foucault's thesis, introduced in his lectures on psychiatric power between 1973 and 1974, could serve as a good point of departure. In his lectures held on January 23, 1974 and January 30,1974 , Foucault called attention to the peculiarities of psychiatric diagnostics which distinguish it from other fields of medicine and medical knowledge in general. He argues that diagnostic practice in psychiatry is only seemingly based on the methodology of differential diagnostics, meaning that a diagnosis is made based on the anamnesis, the observed symptoms, and possible underlying reasons. Foucault argues that, in reality, "medical knowledge in psychiatry functions at the point of the decision between madness and non-madness." 30 Furthermore, he describes psychiatry as a field which does not focus on the body/soma, even though the development of psychiatry was dominated from the beginning by the pursuit of determining the underlying physiological causes of madness (neurological disorders, injuries). But even if psychiatric knowledge is constituted based on the medical observation of signs and symptoms, the question as to whether a patient is mad or not, whether they are simulating their symptoms or not, remain at the core of psychiatric diagnostics. And to determine this, doctors need procedures that could serve as substitutes for the techniques applied in general medicine in order to accept the individual as a patient and for the patient to accept them as doctors. ${ }^{31}$ This approach, however, disregards the fact that, from the 1820 s to the 1860 s, especially in the first decades, the very period Foucault discusses, we can only talk about "psychiatric power" and the success of such techniques if the people who were diagnosed with mental disorders were in fact admitted to institutions specializing in psychiatric problems, where madness was evaluated, described, and treated as, first and foremost, a psychological (mental, behavioral) problem. But what about those institutions where "mental" disorders were diagnosed without the intentions and especially the means of psychiatric normalization? How did general physicians approach the problem in the first half of the nineteenth century?

30 Foucault, “23 January 1974,” 251.

31 Foucault, "23 June 1974," 250-51. 
As mentally ill patients with different diagnoses, especially but not exclusively in the East Central European region, were more often than not taken into the care of policlinics, general hospitals, poor houses, and other non-specialized institutions, in short, outside the world of psycbiatry, the problem of psychiatric diagnostics and the treatment of patients in need of specialized treatment brings up a set of issues and has further implications for (proto)psychiatric care and institutionalization in the region. To underpin this argument, I have chosen to focus on several factors (the naming of the disease, as well as its description and progress, the anamnesis, including the body of the "suffering family," the point of view of the narratives, and the length of stays in hospitals) that help us determine whether the diagnostic and therapeutic practice of the different institutions pertained to a somatic and/or a psychological approach to mental disorders.

From among the five institutions examined in this study, it is, not surprisingly, the practice of the York Retreat that conformed more or less to the requirements described by Foucault, as far as one can tell on the basis of Samuel Tuke's idealistic accounts and the casebooks. In almost all cases, the entries in the casebooks serving both as patient registers and clinical journals with short synoptic case histories contained a diagnosis. These diagnoses, ${ }^{32}$ instead of using common nosological categories and, if viewed from the Foucauldian perspective, somewhat "artificial" medical terminology, reveal a decision concerning whether the patient in question was mad or not. The patients received their diagnostic labels based on their temperament or behavioral and mental symptoms, such as derangement, deranged; insane, insanity; of the melancholiac kind; melancholic derangement, or mental anxiety.

The practice of the physicians in the early asylums of the Habsburg Monarchy, however, following the nosologies of Willis, Sauvages, and Heinroth, suggest that they relied more closely on differential diagnostics and less on the decision as to whether a given patient was mad or not. This observation on my part might of course be distorted, as both Riedel and Viszánik included model cases in their accounts, including accurate indications of which physicians' nosologies they were following. The everyday, raw experiences of diagnostic practice are thus lost here. Among the case histories, they labelled patients with (by early nineteenth-century standards) modern categories, such as melancholic monomania (monomania melancholica) and more common and older categories, such

32 See the naming of the diseases in Table 2. 
as puerperal mania (mania puerperalis), acute mania (mania acuta), pure or simple melancholy (reine Melancholia, melancholia simplex), or mania (reine Tollheit, mania simplex). ${ }^{33}$ In case of the policlinics, where somatic medicine prevailed, almost all patients were diagnosed either with hysteria, hypochondria, or, in a few cases, delirium tremens (confusion or mania caused by the withdrawal of alcohol). The leading diagnosis, hysteria, an elusive disease which could have significant mental symptoms and was classified as a neurological or mental disorder, could also be interpreted, as underlined by the case histories, as a somatic disease with typical symptoms, such as clavus and globus bystericus, gastrointestinal, and menstrual problems.

Foucault's other suggestion about the pre-history of patients and its correlations with diagnostic practice, however, could be relevant here with some modifications. According to Foucault, the decision between madness and nonmadness (or, depending on the context and situation, the method of making differential diagnoses) required the technique of questioning or the search for signs in one's family history to identify the moments when madness surfaced in some way or another. This, though rather fragmentarily, surfaces in the case histories, though probably requiring a slightly different interpretation than the original Foucauldian take on the problem.

Closely related to the above point, Foucault also suggests that questioning served as a substitute for the methodology of pathological anatomy in making a differential diagnosis. When it came to mental disorders, as the tools offered by pathological anatomy were not sufficient to decide between madness and non-madness, family history gained a special significance. Constituting the body of the "suffering family" by extending the scale of examination beyond the individual, a physician could discover signs and connections suggesting one's predisposition to madness. ${ }^{34}$ Interrogating patients about their family history has been a common method in general medicine for centuries. In psychiatric diagnostics, however, as Foucault argues, it is of vital significance for the right choice between madness and non-madness. As suggested earlier, however, Foucault ignores the frequent use of labels in the 1820s and 1830s (and in Hungary, even later ${ }^{35}$ ), such as melancholy, mania, hypochondria, or hysteria,

33 Riedel, Prag's Irrenanstalt, 50-109; Viszánik, Leistungen und Statistik, 91-143. See the cases in Tables 3 and 4.

34 Foucault, “30 January 1974,” 271.

35 In Hungary, even after the first asylums were opened (such as the Schwartzer Private Asylum or the Lipótmező Royal National Asylum), patients diagnosed with mental disorders, mostly insanity, hysteria, 
or simply madness, outside of specialized institutions. Even though questioning and the family history were fundamental parts of the case histories, connections between madness, the suffering family, and the patients' status at the time are rarely revealed. ${ }^{36}$

At the university clinic of Pest, the medical history of the mentally ill patients' parents was recorded in 17 cases. ${ }^{37}$ If we consider those patients only, whose diagnosis was, as revealed by the narratives, based on behavioral and mental symptoms, very laconic references are made to the early signs of madness described by Foucault. Sigismundus Fekete, a 26-year-old patient who suffered from erotomania, a peculiar delusional disorder, was admitted to the clinic on July 19, 1826. Johannes Slavik, a 23-year-old melancholic patient, was admitted two years later, on November 27, 1828. According to his case history, Sigismundus Fekete had healthy parents, and the only health-related event in his anamnesis was that he had received the smallpox vaccine as a child. ${ }^{38}$ Johannes Slavik, however, had a more detailed family history and anamnesis: according to the records, his father died of tuberculosis (phthisis), and ten years prior to his hospitalization he had already had a melancholic episode, and his current episode had begun ten days earlier. ${ }^{39}$ Here, the signs to which Foucault referred are clearly identifiable both in terms of the distant past and recent events. The hereditary nature of the disease surfaces in only one anamnesis: the mother of Anna Nagy, a 25-yearold hysteric patient, also suffered from hysteria ("ex mater hysterica"), however, as hysteria was approached as a primarily somatic disease in these case histories, the phenomenon described by Foucault applies to this case with restrictions.

References to the patients' mental state in other significant, standard sections of the case histories, such as their health status upon admission (status praesens) and the progress of the disease (decursus morbi), are also relatively scarce. In early nineteenth-century medicine, which did not have modern diagnostic measures

\footnotetext{
and delirium tremens, were admitted to the wards of general hospitals. After admission and observation, they were either referred to the Lipótmező asylum or remained in the general hospital, so several of them were treated and discharged from institutions that provided care for them but were outside the realm of psychiatry. See for example the patient records of the St. John's Hospital in Buda: BFL 1103.a. St. John's General Hospital, General Administration, vols. 4-15. Patient Records (1857-1873).

36 At the Edinburgh policlinic, the anamneses contained references neither to family history nor to mental symptoms. Only the physical symptoms preceding hospitalization were recorded. See the cases of the Royal Infirmary in Table 5.

37 See the cases of the teaching clinic of Pest in Table 6.

38 OSZK Kt. Quart. Lat. 2165. Vol. XXIII, 43r.

39 OSZK Kt. Quart. Lat. 2165. Vol. XXVIII, 122r-v.
} 
and tools, the patients' own reflections on their conditions and symptoms were vital for making the correct diagnosis. In cases of mental disorders, getting to know the inner world of patients is all the more important, as the observable (behavioral) phenomena are insufficient to give a reliable account of their condition, its seriousness, and its curability. At this point, the patients' or their relatives' perspective ${ }^{40}$ often filtered into the narratives. In the case histories of the teaching clinics of Pest and Edinburgh, the patients' complaints are often recorded in the third-person singular (accusat, complains). And even though these utterances are filtered and mediated by the physicians' perspective and are organized into coherent narratives by them, in these instances, however rare they may be, the physician's gaze orienting the narration and the "lived" experience of patients are juxtaposed.

In most cases, the physicians' perspective prevails. When the hysteric or hypochondriac patients' mental symptoms are reflected on briefly, we have characterizations like "choleric, nervous and anxious behavior and proneness to sadness" in the case of Elizabeth Szabó, ${ }^{41}$ who was admitted to the clinic on January 30, 1815, or "sadness with misanthropy" in the case of Ferenc Schober, ${ }^{42}$ admitted on December 19, $1823 .{ }^{43}$ Sometimes, however, the patients' complaints are clearly discernible from the narratives, and though they mostly give accounts of their physical pain, they sometimes reflect on their mental state, such as Elizabeth Enzmann, a 40-year-old patient, who was admitted to the teaching clinic of Pest on November 25, 1817 with severe emesis and hysteria. Enzmann complained of anxiety ("accusat anxietates") to the medical student examining her. As for the teaching wards of the Edinburgh Royal Infirmary, the patients complained of a wide array of symptoms, from toothaches to globus bystericus. However, their inner lives, feelings, and mental pain either remained concealed from their doctors or the doctors did not consider them important enough to record in the case histories. Whichever the case, this clearly indicates the absence of a psychological approach, and even though there are counterexamples to this tendency, by and large, the same conclusions hold for the teaching clinic of Pest.

\footnotetext{
40 SEL 50/a, HM 313. 8.

41 The role of relatives is clearly discernible from the anamnesis of the eleventh case of the Prague asylum (reine Willenlosigkeit, abulia simplex). According to this, nobody in the family had paid attention to the mental problems of the patient, only her older sister, who had also provided the necessary details for the anamnesis. ("Sie war traurig, doch achtete Niemand auf ihrer Zustand, als eine ältere Schwester, die die Erzählerin der hier gegebenen anamnetischen Verhältnisse ist.’') Cf. Riedel, Prag's Irrenanstalt, 92.

42 OSZK Kt. Quart. Lat. 2165. Vol. 1, 336v-359v.

43 OSZK Kt. Quart. Lat. 2165. Vol. XIX, 252r-253v.
} 
The case histories recorded in the asylums, also in the third-person singular, allowed slightly more space for the patients' own perspectives. In the casebooks of the York Retreat, in the synoptic summaries of the patients' condition, complaints were rarely included, and even if they were, the entries mostly gave accounts of physical pain. Michael Viszánik and Josef Gottfried von Riedel, however, often devoted more space to the patients' experiences of (mental) pain and recovery. These tendencies are most discernible from the anamneses and the progress sections. The anamneses not only detail the health-related events of the patients' lives from childhood to adulthood but also reflect on the sociocultural settings from which they came. Their path to the asylums, organized into a narrative by the physicians, reveal much about the conditions, family background, and chances of (re)integration into society. Some of the experiences point towards the accidental nature of madness and its underlying reasons, such as changes in one's personal environment. This is well illustrated by the case of an unnamed female patient admitted to the Prague asylum on January 28, 1828. Her melancholic sadness, boredom, and suicidal tendencies were induced by her husband's alcoholism, even though she had led a happy, cheerful life before. ${ }^{44}$ On the other hand, through these narratives, we can catch a glimpse into how a patient's attitude and mental condition changed over the course of treatment and how they gradually opened up to their caretakers. A female patient admitted to the Prague asylum in December 1829 with pure madness (reiner Wabnsinn, ecstasis simplex), completely unaware of her condition, responded well to the treatment, and on the seventh day of her stay, she shared the unknown details of her path to the asylum and began to accept her condition. ${ }^{45}$ And even if she is not heard, the narrative, the case history's progress and therapy sessions illustrate that moral therapy and one of its most important components, conversation with patients, was known and practiced in the Prague asylum, in a setting still dominated mostly by somatic medicine.

Observation and therapy at the policlinics of Pest and Edinburgh were often influenced by the bookish knowledge which the students were expected to acquire during their theoretical courses, neither of which were specialized in the practical approaches to empirical psychology or psychiatry. ${ }^{46}$ Though

\footnotetext{
44 Riedel, Prag's Irrenanstalt, 80-87.

45 Ibid., 57-58.

46 The pathology textbook of Johann Nepomuk Raimann (1780-1847), which was in use in Pest, Vienna, and Prague, contained the distilled definition of hysteria based on popular descriptions of the disease. Raimann classified hysteria as a neurological disorder and considered it essentially the same as
} 
mental symptoms, along with lifestyle and sociocultural dimensions, were part of the textbook definition of hysteria, in the clinical setting, these aspects were seemingly negligible and were not considered fundamental for identifying and diagnosing a certain disease. In case of both Pest and Edinburgh, there seem to have been two dominant sets of symptoms. One of these clusters included gastrointestinal symptoms, excessive stool and urine, pains, and severe cramps. Though it is not mentioned explicitly in any of the sources, this was probably understood in the context of the theory of vapors, which (it was thought), by rising from the stomach and bowels, were responsible for disturbing the mental faculties.

On the other hand, case histories point to the unyielding persistence of the gynecological interpretation of hysteria, with regular references to the disturbances of the menstrual cycle. From among the 18 hysteric patients in Pest, the date of the first period is recorded (between 11 and 17 years of age), and the changes or disorders of the cycle (excessive bleeding or the lack of periods for longer of shorter intervals) were directly linked to the appearance of hysteria and its progress. Other textbook symptoms included lockjaw or trismus, globus and clavus bystericus, and the so-called hysteric fits, the nature of which are rarely reflected on in the case histories, even though they were rather common. In Edinburgh, almost all case histories contained some reference to them. ${ }^{47}$

Therapeutic measures matched the dominant symptoms of the disease at the policlinics. As the therapy sessions in the case histories testify, the theoretical basis of healing was based on the Hippocratic and Galenic system of medicine, still dominant in the early nineteenth century, aiming to restore the balance of the four humors with bloodletting, clysters, and emetics (wild senna, ipecacuanha,

\footnotetext{
hypochondria, but while hypochondria was considered as the disease of young male patients, hysteria was seen as exclusive to women. In Raimann's description, the nature of the disease was rather changeable and elusive, and diagnosing it was a challenge, only possible when a cluster of symptoms could be observed together. As their naming shows, hysteria allegedly originated in the womb (byster), whereas hypochondria was the result of disturbances in the upper two regions of the abdomen (bypochondrium). Their common symptoms were fear of (abnormal) bodily changes, delusions, pain, and cramps localized at certain points of the body (periodic or permanent), gastrointestinal symptoms, changes in temperature, skin problems, weak and uneven pulse, nausea, hearing loss, changes in taste and smell. Typical of hysteria were globus bystericus (lump in the throat) and clavus bystericus (sharp headache localized at one point as if a nail was driven into the skull). Cf. Raimann, Handbuch, 634-35.

47 The 14-year-old hysteric patient, Jane Murray, who was admitted to the Royal Infirmary on March 3, 1801, suffered from multiple fits during her 22-day hospitalization (she then ran away from the hospital). One of these fits was induced when she saw another patient falling into a hysterical fit. Its nature, however, is not detailed by the case history. Cf. RCPE DEP/ABJ/1/1/9, 30-37.
} 
asafetida). These measures were complemented with herbal remedies (valerian, chamomile, lemongrass, opium, or henbane) and chemically distilled oils (peppermint, cinnamon, and wild orange) serving as sedatives, which became widely popular in the eighteenth century with the spread of the neurological approach.

As for therapeutics, the early asylums of the Habsburg Monarchy were transitional between two poles on our scale, the two policlinics and the York Retreat, where references to the practice of moral therapy surface not only in Samuel Tuke's accounts, but also in the case histories. ${ }^{48}$ In Viszánik's and Riedel's case histories, the more traditional, somatic approach is complemented by some components of moral therapy, typically those that were feasible in an urban setting. In the two asylums, in addition to the abovementioned therapeutics, cold baths were also in use as an early form of hydrotherapy ${ }^{49}$ Since one of the cornerstones of moral therapy, the assignment of activities to the patients in a natural setting and useful occupation in, for example, gardens, was not necessarily possible in Prague or Vienna, the two physicians, especially Riedel, paid attention to conversations with patients and to the task of making the environment more bearable by, for example, furnishing and equipping the wards in a "friendlier" manner. ${ }^{50}$

As a final aspect, it is worth looking at the lengths of stays in hospitals. By the turn of the eighteenth and nineteenth centuries, most physicians realized that mental disorders could be rather persistent, and since healing (if possible) or at least subduing symptoms in general took much longer than the treatment of other (somatic) ailments, patients usually needed longer periods of hospitalization. The length of stay (LOS) is thus a good indicator of both the approaches to mental

48 Rachel Raw, a 43-year-old patient haunted by wild visions, could take walks regularly and was given smaller tasks during her long stay in the asylum, while the 36-year-old Abigail Smith spent her time making pincushions, a meaningful activity that was supposed to advance her recovery. The 54-year-old Mary Atkinson and the 46-year-old John Young, both of whom were labeled "deranged," were cured with baths in the sea. There were, however, cases in which the superintendents of the asylum had to turn to restrictive measures and punishment due to the danger the patients posed for themselves and the people around them. The 29-year-old maniac Lydia Brown, for example, was restrained and observed continuously, whereas the 43-year-old John Baker was put in a straitjacket. Cf. Borthwick Institute for Archives RET 6/5/1/1/A, no. 2 (Rachel Raw); no. 18 (Mary Atkinson); no. 34 (John Baker); no. 35 (John Young); no. 183 (Abigail Smith); no. 189 (Lydia Smith).

49 Viszánik, Leistungen und Statistik, 115-16 (melancholia cum convulsionibus); 141-42 (monomania anglica).

50 "Nun (den 16. Februar) war der Zeitpunkt gekommen, wo von einer Aenderung des Lokals aus der düstern Kammer in ein freundliches Zimmer in voraus eine günstige Wirkung erwartet werden durfte." Riedel, Prag's Irrenanstalt, 83. 
normalization and the possibilities hospitals had in offering treatments for patients inflicted with mental disorders. From the perspective of this last consideration, the average length of hospitalization underpins the tendencies observed in the respective sections of case histories, such as the anamnesis (illness-related events in one's family or personal history), diagnosis (especially the naming of the disease), or the progress and therapy sections including the applied curatives and other measures (conversation, change in environment, etc.).

The teaching clinics of Pest and Edinburgh were on the low end of the scale: in the case of Pest, the length of hospitalization can be calculated in 19 of the 22 cases, with the average length of stay (ALOS) being 47 days (approximately 1.5 months). The shortest period of hospitalization was five days (Rosalia Hany, diagnosed with hysteria ${ }^{51}$ ), while it was the melancholic Johannes Slavik ${ }^{52}$ who spent the longest time in the clinic, 228 days altogether. This, at the same time, reflects on the differences between the interpretations of hysteria (primarily a somatic disease and curable as such) and melancholy (primarily a mental disorder, identifiable on the basis of mental and behavioral symptoms). Similar tendencies prevailed in Edinburgh, with the average length of stay being even lower (23 days). The shortest stay was the hysteric Elisabeth Erskine's ${ }^{53}$ (six days), whereas the maniac John Williamson ${ }^{54}$ stayed for 50 days in the teaching ward of the Royal Infirmary.

As for the two asylums considered "transitional" institutions, the ALOS differed significantly: in Vienna it was only 62 days (ca. 2 months) and in Prague it was twice this, 134 days (ca. 4.5 months). The highest ALOS was, as expected, in the York Retreat. However, it must be noted that the dates in the casebooks are rather unreliable due to the frequent readmissions and follow-up care provided for the patients (when it was possible, the superintendents of the asylum paid attention to their patients even after they were discharged). It is therefore in most cases impossible to work with exact numbers, and that is why I have chosen to rely only on 42 cases in which the dates of admission and discharge were given precisely (a further twelve cases ended with death, among them one suicide). Basing my calculations on the selected cases from between 1796-1800 and 1815-1820, the ALOS was 632 days (ca. 21 months), with the lowest stay being 34 days and the highest being 2,790 days (ca. 93 months).

51 OSZK Kt. Quart. Lat. 2165. Vol. VIII, 295r-296v.

52 OSZK Kt. Quart. Lat. 2165. Vol. XXVIII, 122r-125v.

53 RCPE DEP/ABJ/1/1/5, 37-39.

54 RCPE AWP/2/5, 90-94. 
Table 1.

Lengths of stay and average lengths of stay in the hospitals

\begin{tabular}{|l|c|c|c|}
\hline \multicolumn{1}{|c|}{ Institution } & Shortest LOS & Longest LOS & ALOS \\
\hline University clinic of Pest & 5 & 228 & 47 \\
\hline University clinic of Edinburgh & 6 & 50 & 23 \\
\hline Vienna asylum & 12 & 180 & 62 \\
\hline Prague asylum & 15 & 273 & 134 \\
\hline York Retreat & 34 & 2790 & 632 \\
\hline
\end{tabular}

If we consider the length of stay a good indicator of the seriousness of a disease and the efficacy of mental normalization, these numbers clearly show that, from among the institutions under discussion, it was indeed the model asylum that could fulfil its function of conducting therapy, the two asylums of the Habsburg Monarchy integrated the newest approaches and older methods (purging, bloodletting etc.), while the two policlinics only took on the responsibility of subduing (somatic) symptoms and offering a temporary asylum for those showing the symptoms of disorders classified as "mental." As for the teaching clinic of Pest in the focus of my inquiry, both the methods of identification and therapy indicate that the medical students who were completing their practical semesters and who did not take practical courses on psychiatry could only rely on knowledge they gathered from the rather scattered material in diverse courses (introductory courses on empirical psychology focusing on the basic outlines of the cognitive faculties, physiology, pathology, therapeutics, medical police, and forensic medicine). Thus, even though psychological knowledge gradually filtered into the curricula and textbooks of the Medical Faculty of the University of Pest, in the absence of a specialized institution, a psychological approach would have been impossible to implement in practice, and this necessitated the fundamentally somatic approach to the treatment of patients labeled as mentally ill (or diagnosed with maladies disguised as such). However, it must also be underlined that the period between the end of the eighteenth century and the 1830s marks a turning point in the history of psychiatry in Hungary, and even if we can only talk about a belated introduction of the psychological approach in medical practice, the mere fact that patients with these conditions were even accepted into the policlinic after the 1810s was a great step towards reconsidering the attitudes towards their treatment, which was addressed in both theoretical approaches and practice more intensely after the 1830s. 


\section{Archival Sources}

Archiv der Universität Wien (UAW)

Sonstige Archive, Josephsakademie (k. k. medizinisch-chirurgische Militärakademie) und Garnisonsspital, Wissenschaftliche Elaborate, Krankengeschichten.

Borthwick Institute for Archives, University of York

York Retreat, Casebooks, 1-3.

RET 6/5/1/1/A (Volume 1, 1796-1828)

RET 6/5/1/1/B (Volume 2, 1803-1820)

RET 6/5/1/2 (Volume, 1828-1838)

Budapest Főváros Levéltára [Budapest City Archives] (BFL)

1103.a. St. John's General Hospital, General Administration, vols. 4-15. Patient Records (1857-1873).

Országos Széchényi Könyvtár Kézirattár [Manuscripts Archive of National Széchényi Library] (OSZK Kt.)

Quart. Lat. 2165. Historia morborum, in clinico medico... Scientiarum Universitatis ab anno scholastico 1815/1816. usque ad annum 1838/1839. tractatorum, descriptae per candidatos medicinae, Pestini.

Quart. Lat. 2166. Relationes de aegris in instituto chirurgico-practico... Universitatis Scientiarum... tractatis Pestini ab anno scholastico 1816/1817. usque ad annum 1840/1841. descriptae per assistentes ac auditores.

Quart. Lat. 2168. Conspectus synopticus in clinico medico practico Regiae Scientiarum Universitatis Hungaricae ab anno 1814. usque ad annum 1824. pertractatorum, per assistentes et auditores conscriptus, Pestini.

Quart. Lat. 2169. Synopsis observationum practicarum circa aegros in instituto medico-practico Regiae Scientiarum Universitatis Hungaricae, sub auspiciis domini professoris Joannem Pozsonyi assistentes. Pestini, 1818-1821.

Quart. Lat. 2172. Brevis eorum expositio, quae et quomodo in clinico medico Regiae Scientiarum Universitatis Hungaricae manu ducente... professore Francisco Bene acta sunt... Descripta per Josephum Krieger (1818).

Royal College of Physicians of Edinburgh Archives (RCPE)

$\mathrm{DEP} / \mathrm{ABJ} / 1-2$ : Men's Cases (1800-1801)

$\mathrm{DEP} / 1 / 1 / 5-9$ : Women's Cases (1801)

DEP/AWP/2/1-6: Cases taken from the Clinical Journals of the Royal Infirmary of Edinburgh (1809-1811)

DEP/AWP/2/7-8: Clinical case notes (1811)

DEP/HOT/1: Clinical Casebook (1796-1797) 
DEP/LID/1: Clinical Case notes (1812)

Semmelweis Egyetem Levéltára [Semmelweis University Archives] (SEL)

1/g, Annual Reports of the Clinics of the Medical Faculty, 1825-1835, Boxes 1-3.

$50 / \mathrm{a}$, Historiae Morborum

\section{Bibliography}

Primary sources

Heinroth, Johann Christian August. Lebrbuch der Störungen des Seelenlebens oder der Seelenstörungen und ihrer Behandlung, 1-2. Leipzig: Bei E. H. F. Hartmann, 1818.

Raimann, Johann Nepomuk von. Handbuch der speciellen medicinischen Pathologie und Therapie für akademische Vorlesungen, zweyter Band, zweyte vermebrte und verbesserte Auflage. Wien: Bey Friedrich Volke, 1826.

Riedel, Joseph Gottfried. Prag's Irrenanstalt und ibre Leistungen in den Jahren 1827, 1828 und 1829. Prag: Calve, 1830.

Sauvages, François Boissier de. Nosologia methodica sistens morborum classes, genera et species juxta Sydenhami mentam et Botanicorum ordinem. Amsterdam: Frère des Tournes, 1763.

Stoll, Maximilian. Heilungsmethode in dem praktischen Krankenhause zu Wien. Zweyter Theil, Erster Band. Breßlau: Bey Johann Friedrich Korn, dem ältern, 1784.

Stoll, Maximilian. Heilungsmethode in dem praktischen Krankenhause zu Wien. Dritter Theil, Erster Band. Breßlau: Bey Johann Friedrich Korn, dem ältern, 1786.

Stoll, Maximilian. Heilungsmethode in dem praktischen Krankenhause zu Wien. Fünfter Theil, Erster Band. Breßlau-Hirschberg: Bey Johann Friedrich Korn, dem ältern, 1793.

Tuke, Samuel. Description of the Retreat, an Institution Near York for Insane Persons of the Society of Friends. York: Printed for W. Alexander, 1813.

Tuke, Samuel. Practical Hints on the Construction and Economy of Pauper Lunatic Asylums. York: Printed for William Alexander, 1815.

Viszánik, Michael von. Leistungen und Statistik der k. k. Irrenheilanstalt in Wien seit ibrer Gründung 1784 bis 1844. Wien: Mörschner, 1845.

Willis, Thomas. Pathologiae cerebri et nervosi generis specimen, in quo agitur de morbis convulsivis et de scorbuto. Oxford: Hall, 1667.

Secondary literature

Aaslestad, Petter. The Patient as Text: The Role of the Narrator in Psychiatric Notes, 18901990. Oxford: Radcliffe 2009. 
Andrews, Jonathan. "Case Notes, Case Histories, and the Patient's Experience of Insanity at Gartnavel Royal Asylum, Glasgow, in the Nineteenth Century." Social History of Medicine 11, no. 2 (1998): 255-81.

Andrews, Jonathan and Andrew Scull. Customers and Patrons of the Mad-Trade: The Management of Lunacy in Eighteenth-Century London, With the Complete Text of John Monro's 1766 Case Book. Berkeley, CA-Los Angeles, CA-London: University of California Press, 2002.

Bacopoulos-Viau, Alexandra and Aude Fauvel. "The Patient's Turn. Roy Porter and Psychiatry's Tales, Thirty Years On.” Medical History 60, no. 1 (2016): 1-18. doi: 10.1017/mdh.2015.65.

Bal, Mieke. Travelling Concepts in the Humanities: A Rough Guide, 22-55. Toronto-BuffaloLondon: University of Toronto Press, 2002.

Becker, Peter and William Clark, eds. Little Tools of Knowledge: Historical Essays on Academic and Bureaucratic Practices. Ann Arbor, MI: The University of Michigan Press, 2001.

Berkenkotter, Carol. Patient Tales. Case Histories and the Uses of Narrative in Psychiatry. Columbia, SC: The University of California Press, 2008.

Blair, Ann. "Reading Strategies for Coping with Information Overload, ca. 1550-1700." Journal of the History of Ideas 64, no. 1 (2003): 11-28. doi: 10.2307/3654293.

Chase, Ronald. The Making of Modern Psychiatry Berlin: Logos Verlag, 2018.

Condrau, Flurin. “The Patient's View Meets the Clinical Gaze.” Social History of Medicine 20, no. 3. (2007): 525-40. doi: 10.1093/shm/hkm076.

Craig, Stephen C. "Enquire into All the Circumstances of the Patient Narrowly": John Rutherford's Clinical Lectures in Edinburgh, 1749-1753." Journal of the History of Medicine and Allied Sciences 72, no. 3 (2017): 302-27.

Daston, Lorraine. "Taking Note(s)." Isis 95, no. 3. (2004): 443-48.

Daston, Lorraine. "The Empire of Observation." In Histories of Scientific Observation, edited by Lorraine Daston and Elizabeth Lunbeck, 82-113. Chicago, IL:

The University of Chicago Press, 2011. doi: 10.7208/9780226136790-005.

Digby, Anne. Madness, Morality and Medicine: A Study of the York Retreat, 1796-1914. New York, NY: Cambridge University Press, 1985.

Michel Foucault. "23 January 1974” In Psychiatric Power: Lectures at the Collège de France, 1973-1974, edited by Jacques Lagrange, translated by Graham Burchell, 233-54. Basingstoke: Palgrave Macmillan, 2006.

Michel Foucault. "30 January 1974." In Psychiatric Power: Lectures at the Collège de France, 1973-1974, edited by Jacques Lagrange, translated by Graham Burchell, 265-95. Basingstoke: Palgrave Macmillan, 2006. 
Geyer-Kordesch, Johanna. "Comparative Difficulties: Scottish Medical Education in the European Context (c. 1690-1830)." In The History of Medical Education in Britain, edited by Vivian Nutton, and Roy Porter, 94-115. Amsterdam-Atlanta, GA: Rodopi, 1995.

Goody, Jack. The Logic of Writing and the Organisation of Society. Cambridge: Cambridge University Press, 1986.

Hess, Volker. "Formalisierte Beobachtung. Die Genese der modernen Krankenakte am Beispiel der Berliner und Pariser Medizin (1725-1830)." Medizinhistorisches Journal 45 (2010): 293-340.

Hess, Volker and Sophie Ledebur. "Taking and Keeping: A Note on the Emergence and Function of Hospital Patient Records." Journal of the Society of Archivists 32, no. 1 (2011): 21-33. doi: 10.1080/00379816.2011.563102.

Hess, Volker and Andrew J. Mendelsohn. "Case and Series: Medical Knowledge and Paper Technology, 1600-1900.” History of Science, 48, no. 3-4 (2010): 287-314.

doi: $10.1177 / 007327531004800302$.

Hunter, Kathryn Montgomery. Doctor's Stories: The Narrative Structure of Medical Knowledge.

Princeton, NJ: Princeton University Press, 1991.

Hurwitz, Brian. "Form and Representation in Clinical Case Reports." Literature and Medicine 25, no. 2 (2006): 216-40. doi: 10.1353/lm.2007.0006.

Ingram, Allan. The Madhouse of Language: Writing and Reading Madness in the Eighteenth Century. London: Routledge, 1991.

Kennedy, Margaret Ann. "A Curious Literature: Reading the Medical Case History from the Royal Society to Freud.” PhD Diss., Brown University, 2000.

Kovács, Janka. "Elmebetegügy a 18-19. század fordulóján: elméleti keretek, konaepególdási javaslatok." [Mental health policy at the turn of the eighteenth and nineteenth centuries: Theoretical framework, concepts, proposals]. Korall71 (2018): $7-26$.

Kovács, Janka. “Az orvostudomány 'legsetétebb mezeje’: Pszichológiai ismeretek a Habsburg Birodalom orvosi fakultásainak tananyagában a 18-19. század fordulóján.” [The "darkest field" of medicine: Psychological knowledge in the curricula of the medical faculties of the Habsburg Monarchy at the turn of the 18th and 19th centuries]. Gerundium Egyetemtörténeti Kö̈lemények 11, no. 3-4 (2020): 78-103.

Krász, Lilla. "From Home Treatment to Hospitalisation: General Trends in the Development of Hungary's Hospital Network." In Europäisches Spitalwesen. Institutionelle Fürsorge in Mittelalter und Früher Neuzeit / Hospitals and Institutional Care in Medieval and Early Modern Europe, edited by Martin Scheutz, Andrea Sommerlechner, Herwig Weigl and Alfred Stefan Weiss, 455-73. Vienna-Munich: Böhlau, 2008. 
Krász, Lilla. “Az adatoktól az információig, az információtól a tudástermelésig: Az egészségügyijelentés-írás gyakorlata(i) a XVIII. századi Magyarországon.” [From data to information, from information to knowledge production: The practice(s) of writing medical reports in 18th-century Hungary]. Századvég 70 (2013): 155-87. Krász, Lilla. "Theoria medica és praxis medica: A tudásközvetítés változó útjai a medicinában a 18. század második felében" [Theoria medica and praxis medica: The changing methods of knowledge transfer in medicine in the second half of the 18th century]. Századok 151, no. 5 (2017): 1025-42.

Krász, Lilla. “Táblázatokba zárt tudás? Az orvosi tudásszervezés gyakorlatai a 18. századi Magyarországon" [Knowledge arranged into tables? Practices of knowledge organization in 18th-century Hungary]. Kaleidoscope 13 (2018): 223-50.

Krász, Lilla. "'Observing to describe, describing to observe': The Epistemic Turn of Medical Writing in the 18th Century." Hungarian Studies 33 (2019): 175-84.

Mendelsohn, Andrew J. "Empiricism in the Library." In Science in the Archives: Pasts, Presents, Futures, edited by Lorraine Daston, 85-109. Chicago, IL: Chicago University Press, 2017.

Pomata, Gianna. "Sharing Cases: The Observationes in Early Modern Medicine." Early Science and Medicine 15, no. 3 (2010): 193-236.

Porter, Roy. "The Patient's View. Doing Medical History from Below." Theory and Society 14, no. 2 (1985): 175-98.

Rédei Ildikó. Historiae morborum: Kórtörténetek a 18-19. száąadból [Historiae morborum: Case histories from the 18th and 19th centuries]. Budapest, Semmelweis Kiadó, 2016.

Geoffrey Reaume. "From the Perspectives of Mad People." In The Routledge History of Mental Health, edited by Greg Eghigian, 277-96. London: Routledge, 2017.

Risse, Guenter B. Hospital Life in Enlightenment Scotland: Care and Teaching at the Royal Infirmary of Edinburgh. Cambridge: Cambridge University Press, 1986.

Risse, Guenter B. "Clinical Instruction in Hospitals: The Boerhaavian Tradition in Leyden, Edinburgh, Vienna and Pavia.” Clio Medica 21, no. 1-4 (1987): 1-19.

Scheutz, Martin and Alfred Stefan Weiss. "Spitäler im bayerischen und österreichischen Raum in der Frühen Neuzeit (bis 1800)." In Scheutz et al. eds. Europäisches Spitalwesen, 185-229.

Watzka, Carlos. Vom Hospital zum Krankenhaus: zum Umgang mit psychisch und somatisch Kranken im frübneuzeitlichen Europa. Cologne-Vienna: Böhlau, 2005.

Watzka, Carlos. Arme, Kranke, Verrückte: Hospitäler und Krankenhäuser in der Steiermark vom 16. bis zum 18. Jahrbundert und ihre Bedeutung für den Umgang mit psychisch Kranken. Graz: Steiermärkisches Landesarchiv, 2007. 
Hungarian Historical Review 10, no. 2 (2021): 211-242

\section{Appendix}

Table 2.

Cases of the York Retreat

\begin{tabular}{|c|c|c|}
\hline Name & Age & Diagnosis \\
\hline Margaret Holt & 65 & - \\
\hline Rachel Raw & 49 & - \\
\hline John Ellis & 26 & maniacal \\
\hline Sarah Merill & 50 & insanity \\
\hline Anne Noble & 25 & insanity \\
\hline Joseph Reynolds & 26 & $\begin{array}{l}\text { epileptic } \\
\text { (falsely diagnosed as a lunatic at first) }\end{array}$ \\
\hline Mary Evens & 26 & melancholic insane \\
\hline Mary Pyle & 50 & insane \\
\hline John Bower & 45 & disorder is of the melancholy kind \\
\hline Mary Bayes & 58 & religious insanity \\
\hline Elizabeth Thompson & 56 & insanity of the melancholy kind \\
\hline John Waltonford & 30 & - \\
\hline Thomas Ellein & 39 & religious melancholy \\
\hline Sarah Delves & 55 & insanity, lowness of spirits \\
\hline James Hashold & 32 & derangement \\
\hline William Carcott & 45 & derangement \\
\hline John Richardson & 74 & insanity \\
\hline Mary Atkinson & 54 & deranged \\
\hline Susanna Reynolds & 72 & - \\
\hline Hannah Dumbleton & n. a. & incurable \\
\hline John Fawcett & 45 & \\
\hline John Gundrey & 24 & derangement \\
\hline Hannah Ponsonby & 56 & derangement \\
\hline Abigail Sheppard & 20 & - \\
\hline Mary Prideaux & 45 & derangement \\
\hline Katharine Patchett & 45 & - \\
\hline Joshua North & n. a. & violent derangement \\
\hline James Blouse & 24 & disorder of the melancholy cast \\
\hline Hannah Forster & 24 & - \\
\hline Solomon Chapman & 50 & a mixture of melancholy and mania alternating \\
\hline Sarah Wood & 64 & derangement \\
\hline
\end{tabular}




\begin{tabular}{|c|c|c|}
\hline Name & Age & Diagnosis \\
\hline Samuel Clemesha & 60 & derangement \\
\hline Ann Wallis & 22 & dementia \\
\hline John Baker & 43 & derangement \\
\hline John Young & 46 & derangement \\
\hline Nathaniel Samms & 54 & derangement \\
\hline Ann Gibbins & 38 & derangement \\
\hline Judith Robert & 30 & insanity due to epileptic fits \\
\hline Charles Spencer & 50 & his disorder is of the melancholic kind \\
\hline Thomas Wellington & 48 & hypochondriacal melancholy \\
\hline Richard Gunn & 60 & deranged \\
\hline Mehitabel Moore & 24 & derangement \\
\hline Elizabeth Flint & 20 & of the melancholic kind \\
\hline Elizabeth Frith & 40 & melancholy \\
\hline Hannah Woodewille & 19 & - \\
\hline Susannah Winter & n.a. & epileptic fits, mental derangement \\
\hline Hannah Bradshaw & c. 30 & incurable \\
\hline Mary Dearman & 27 & melancholic Insanity \\
\hline Hannah Young & 22 & hysteria \\
\hline Joseph Lupton & 60 & of the melancholy kind \\
\hline Abigail Smith & 36 & in a state of insanity \\
\hline John Fawcett & 64 & insanity \\
\hline John Akins & 51 & melancholy \\
\hline George Simpson & 23 & religious enthusiasm \\
\hline John Lees & 25 & weak capacity, insanity \\
\hline Sarah Cork & 44 & melancholy \\
\hline Lydia Brown & 29 & insane \\
\hline Elizabeth Bagg & 41 & melancholy derangement \\
\hline Mr [?] Simmson & $?$ & great confusion of ideas \\
\hline Samuel Merill & 22 & - \\
\hline Mary Mantle & 57 & many nervous affections \\
\hline Charles Lloyd & 42 & insanity \\
\hline John Smith & 20 & - \\
\hline John Littlewood & 38 & melancholy kind \\
\hline John Curtis Bentley & 20 & insanity of the melancholy kind \\
\hline Rachel Evans & 24 & derangement \\
\hline Chris Choat & 57 & palsy fit \\
\hline Elizabeth Hamburg & 42 & - \\
\hline
\end{tabular}


Hungarian Historical Review 10, no. 2 (2021): 211-242

\begin{tabular}{|c|c|c|}
\hline Name & Age & Diagnosis \\
\hline John Coleby & 78 & melancholy \\
\hline Henry Perkins & 30 & melancholy derangement \\
\hline Sybela Mallinson & 57 & insane, melancholia \\
\hline Elizabeth Lancaster & $?$ & imbecile state of mind \\
\hline Jane Heslop & 62 & disordered imagination, insanity \\
\hline Thomas Broadbent Bland & 44 & nervous \& hypochondriacal symptoms \\
\hline Mary Simms & 44 & drinking \\
\hline Henry Bearle & 23 & furious mania \\
\hline John Hall & 69 & mania \\
\hline Martha Broadhead & 17 & insanity \\
\hline George Tichell & 29 & mental derangement \\
\hline Mary Fletcher & $?$ & mental derangement \\
\hline Ann Anderson & 24 & - \\
\hline Elizabeth Jardine & 38 & low melancholy state \\
\hline Susan Woodwille & 35 & deranged \\
\hline Owen Weston & 24 & deranged \\
\hline Ann Groves & 22 & - \\
\hline Joseph Ruston & 47 & $\begin{array}{l}\text { insanity } \\
\text { melancholy }\end{array}$ \\
\hline Joseph Russel Warwick & 74 & religious melancholy \\
\hline John Payne & 48 & maniacal symptoms \\
\hline Sarah Midwinter & 31 & - \\
\hline Elizabeth Dickinson & 71 & - \\
\hline Jane King & 57 & - \\
\hline Edward Night & 16 & deranged \\
\hline George Arger & 74 & - \\
\hline Aaron Richardson & 43 & insanity \\
\hline Jane Biggs & 35 & aberration of mind \\
\hline Hannah Laycock & 21 & deranged \\
\hline Mary Oddie & 28 & weak intellect \\
\hline Edwin Swan Rickman & 30 & insane \\
\hline Sarah Field & 48 & insane \\
\hline John Kingston & 28 & imbecility of mind \\
\hline Rebecca Bland & 39 & mental anxiety \\
\hline
\end{tabular}


Table 3.

Cases of the Prague Asylum

\begin{tabular}{|l|c|l|}
\hline Name & Age & Diagnosis \\
\hline N. N. & 24 & reiner Wahnsinn (ecstasis simplex) \\
\hline N. N. & - & Wahnsinn mit Tollheit (ecstasis maniaca) \\
\hline S. W. & 41 & Wahnsinn mit Wahnwitz (ecstasis paranoia) \\
\hline J. F. & 44 & Wahnwitz (ecnoia) \\
\hline P. J. & 46 & Verrücktheit mit Tollheit (ecnoia maniaca) \\
\hline B. M. & 40 & reine Tollheit (mania simplex) \\
\hline R. R. & 40 & $\begin{array}{l}\text { religiöse Melancholie (melancholia religiosa, } \\
\text { melancholia supersitiosa) }\end{array}$ \\
\hline W. B. & 44 & reine Melancholie (melancholia simplex) \\
\hline H. D. & 27 & Blödsinn mit Krämpfen (anoia simplex) \\
\hline F. R. & 28 & reine Willenlosigkeit (abulia simplex) \\
\hline F. S. & 25 & $\begin{array}{l}\text { melancholia metamorphosis, melancholia } \\
\text { zoantropica }\end{array}$ \\
\hline A. U. & 37 & daemonomania \\
\hline R. A. & 23 & reine Scheue (panphobia) \\
\hline
\end{tabular}

Table 4.

Cases of the Vienna Asylum

\begin{tabular}{|l|c|l|}
\hline \multicolumn{1}{|c|}{ Name } & Age & \multicolumn{1}{c|}{ Diagnosis } \\
\hline A. Fr. & 30 & mania \\
\hline W. J. & 39 & delirium tremens potatorum \\
\hline B. G. & 31 & mania \\
\hline W. Al. & 26 & mania acuta \\
\hline M. Th. & 32 & melancholia cum convulsionibus \\
\hline K. Al. & 20 & mania \\
\hline V. Const. & 16 & mania ex onania \\
\hline F. Fr. & 24 & mania \\
\hline H. M. & 27 & mania acuta \\
\hline P. T. & 36 & monomania melancholica \\
\hline G. J. & 30 & mania puerperalis \\
\hline S. J. & 30 & monomania anglica \\
\hline
\end{tabular}


Table 5.

Cases of the Edinburgh Royal Infirmary

\begin{tabular}{|l|c|l|}
\hline \multicolumn{1}{|c|}{ Name } & Age & \multicolumn{1}{c|}{ Diagnosis } \\
\hline Elizabeth Erskine & 28 & hysteria \\
\hline Betty McKay & 53 & hysteria (incurable) \\
\hline Jane Murray & 14 & hysteria \\
\hline Pringle Young & 53 & hypochondria \\
\hline Jane Mitchell & 23 & hysteria \\
\hline Margaret Christie & 25 & cephalagia from hysteria \\
\hline Daniel Hill & 65 & hypochondria \\
\hline John Williamson & 35 & mania \\
\hline Christiane Scroggie & 11 & hysteria \\
\hline Barbara Johnstone & 20 & hysteria \\
\hline
\end{tabular}

Table 6.

Cases of the teaching clinic of the University of Pest

\begin{tabular}{|l|c|l|}
\hline \multicolumn{1}{|c|}{ Name } & Age & \multicolumn{1}{c|}{ Diagnosis } \\
\hline Elisabetha Szabó & 17 & epilepsiae cum hysterismo \\
\hline Anna Obst & 37 & hysterismo cum infarctibus abdominalibus \\
\hline Klara Werl & 22 & hysteria \\
\hline Cunigunda Gramlin & 23 & hysteria \\
\hline Julia Tergoth & 18 & hysteria cum methrorragia \\
\hline Elisabeth Enzman & 40 & vomitus chronicum cum Hysteriasi \\
\hline Barbara Roletsky & 20 & Hysteria cum Epilepsia \\
\hline Rosalia Hany & 18 & Hysteria \\
\hline Maximilianus Hirschl & 31 & Delirium Tremens \\
\hline Anna Skarlein & 21 & Hyperkinesia Hysterica \\
\hline Maria Havrekerin & 26 & Hyperkinesia hysterica \\
\hline Susanna Schedner & 27 & Gastralgia cum Hyperkinesia Hysterica \\
\hline Catharina Koháné & 50 & Hyperkinesia hysterica \\
\hline Maria Steiner & 24 & Hyperkinesia hysterica \\
\hline Franciscus Schober & 33 & Hyperkinesia hypochondriaca \\
\hline Anna Streditzin & 36 & Hyperkinesia hysterica \\
\hline Fekete Sigismundus & 26 & Erotomania \\
\hline Juliana Koszonits & 26 & Rheumatismus cum hyperkinesia hysterica \\
\hline Anna Beck & 16 & Hysteria spasmorum hystericorum \\
\hline Johannes Slavik & 23 & Melancholia \\
\hline Anna Nagy & 25 & $\begin{array}{l}\text { Paralysis rheumatica extermitatum superiorum et } \\
\text { hysterismus }\end{array}$ \\
\hline Anna Maria Navratill & 50 & Hysteria \\
\hline
\end{tabular}

